\title{
The Influence of Seasonalness on the Structural Characteristics of Aquatic Humic Substances Extracted from Negro River (Amazon State) waters: Interactions with $\mathrm{Hg}$ (II)
}

\author{
Luciana C. de Oliveira, ${ }^{a}$ Ézio Sargentini Jr, ${ }^{b}$ André H. Rosa, ${ }^{c}$ Julio C. Rocha, ${ }^{*, a}$ Marcelo L. Simões, ${ }^{d}$ \\ Ladislau Martin-Neto, ${ }^{d}$ Wilson T. L. da Silva ${ }^{d}$ and Ricardo L. Serudo ${ }^{b}$ \\ ${ }^{a}$ Instituto de Química, Universidade Estadual Paulista, CP 355, 14800-900 Araraquara-SP, Brazil \\ ${ }^{b}$ Instituto Nacional de Pesquisas da Amazônia-INPA, Manaus-AM, Brazil \\ ${ }^{c}$ Departamento de Engenharia Ambiental, Universidade Estadual Paulista, 18087-180 Sorocaba-SP, Brazil \\ ${ }^{d}$ Embrapa Instrumentação Agropecuária, 13560-970 São Carlos-SP , Brazil
}

\begin{abstract}
Neste trabalho, substâncias húmicas foram extraídas de amostras de água coletadas mensalmente na Bacia do Rio Negro-AM para estudar suas propriedades no ambiente amazônico e interações com íons mercúrio, considerando a influência da variação sazonal na sua formação. Os parâmetros razões atômicas $\mathrm{C} / \mathrm{H}, \mathrm{C} / \mathrm{N}$ e C/O, grupos funcionais, radicais livres do tipo semiquinona, $\mathrm{pH}$, índices pluviométricos e fluviométricos, concentrações de mercúrio foram interpretados por análise hierárquica de cluster (AHC) e análise de componentes principais (ACP). As análises estatísticas mostraram que, quanto maior o índice pluviométrico e menor o índice fluviométrico maior o grau de humificação das substâncias húmicas aquáticas. A seguinte ordem decrescente do grau de humificação das SHA coletadas mensalmente pode ser estabelecida: Nov/02 a Fev/03 > Mar/02 a Mai/02 > Jun/02 a Out/02. As maiores concentrações de mercúrio foram determinadas nas amostras mais humificadas, sugerindo que devido a rearranjos inter e/ou intramoleculares, quanto maior o grau de humificação maior a afinidade dos íons $\mathrm{Hg}(\mathrm{II})$ pelas substâncias húmicas aquáticas.
\end{abstract}

In this work, humic substances were extracted from water samples collected monthly from the Negro River basin in the Amazon state (Brazil) to study their properties in the Amazonian environment and interactions with the mercury ion considering the influence of seasonalness in this formation. The $\mathrm{C} / \mathrm{H}, \mathrm{C} / \mathrm{N}$ and $\mathrm{C} / \mathrm{O}$ atomic ratio parameters, functional groups, concentration of semiquinone-type free radicals, $\mathrm{pH}$, pluviometric and fluviometric indices, and mercury concentrations were interpreted using hierarchical cluster analysis (HCA) and principal component analysis (PCA). The statistical analyses showed that when the pluviometric index was greater and the fluviometric index was smaller, the degree of humification of aquatic substances was greater. The following decreasing order of the degree of humification of the AHS collected monthly was established: Nov/02 to Feb/03 > Mar/02 to May/02 > Jun/02 to Oct/02. The greatest concentrations of mercury were detected in more humidified samples. These results suggest that due to inter and/or intra-molecular rearrangements, the degree of humification of aquatic humic substances is related to its affinity for $\mathrm{Hg}(\mathrm{II})$ ions.

Keywords: aquatic humic substance, seasonality, Negro River, Amazon, mercury

\section{Introduction}

Fresh water streams have an important function in the global carbon cycle in that they conduct organic matter $(\mathrm{OM})$ of terrestrial origin and transfer it to the

*e-mail: jrocha@iq.unesp.br oceans. ${ }^{1}$ The Amazonian region is home to the most extensive fluvial system which also has greatest liquid mass of the whole earth and it is covered by the largest pluvial tropical forest. According to Bluntschli, ${ }^{2}$ the circulation of marine water through the atmospheric compartment above the forest and then from the forest across the fluvial plains again to the sea has a decisive 
function in the Amazonian ecosystem. According to Sioli, ${ }^{3}$ the forest and the regimes of high-water and lowwater levels of this region are intimately related. The Amazon River has the greatest liquid mass with an average annual outflow of $200,000 \mathrm{~m}^{3} \mathrm{sec}^{-1}$ and drains approximately seven million square kilometers of land submitted to an average annual rainfall of $2,500 \mathrm{~mm}^{3}$. According to Spitzy and Ittekkot, ${ }^{4}$ no other river on this planet transfers more OM to the ocean than the Amazon. The Negro River is a tributary to the Amazon River and has the greatest concentration of dissolved organic material (DOM) at around 600-900 $\mathrm{mol} \mathrm{L}^{-1}$, while other tributaries of the Amazon have 300-500 $\mathrm{mmol} \mathrm{L}^{-1}$ of DOM. ${ }^{1}$ For this reason, the waters of the Negro River are acidic due to this movement of OM derived mainly from extensive areas of hydromorphic podzols from the superior portion of the basin ${ }^{5}$ and according to Ravinchandram, ${ }^{6}$ about $80 \%$ of the DOM is in the form of humic substances.

Humic substances (HS) are amorphic, dark and have a large content of oxygenated organic groups, such as carboxylic, phenolic, enolic, alcoholic and quinone groups, among others. They have an apparent molar mass varying from hundreds to thousands of atomic mass units (a.m.u.) and are resistant to biological and chemical degradation. ${ }^{7,8}$ A structural model for HS has not yet been totally elaborated explaining their chemical composition, structure, form and size. And existing models generate controversy and discussion. ${ }^{9-12}$

Among the existing models, there are proposals, which state that HS are poli-dispersed mixtures of molecules formed by the microbial degradation of animal and plant residue. As for the aquatic humic substances (AHS), the method is based on chromatographic extraction methods. Thurman and Malcolm ${ }^{13}$ define AHS as a non-specific amorphic portion constituted of dissolved organic carbon (DOC) at $\mathrm{pH} 2$ and absorbable in a XAD 8 non-ionic resin column having high distribution-coefficient values. The extracted fraction of DOC in a sample depends on the type of resin utilized, and on the quantity of sample and the eluent utilized. Consequently, samples of AHS extracted using different methods generally are not compatible. The properties of HS in the environment are influenced by their composition and structural characteristics, being controlled by the humification process of the $\mathrm{OM}^{14,15}$ and are dependant on the type of soil, ${ }^{16}$ vegetation ${ }^{17}$ and climatic conditions. ${ }^{18}$

Humification is defined as the transformation of macromorphologically identifiable matter into amorphous compounds, as a rule involving the changes that occur in vegetal residues or soil organic matter. It has been related to the preferential oxidation of plant polysaccharides, the selective preservation of more recalcitrant organic compounds such as lignin and phenolic structures, and to the incorporation of organic compounds of microbial origin. The best method for measuring the degree of humification is still being debated because there is no well-defined structural model of HS structure. 7,14,15 $^{-1}$

Due to the great quantity of linked land areas, the AHS interact with specimen metals in aquatic systems. Therefore, the depositing, the hydro-geochemical cycles and the bio-availability of metals such as mercury, are strongly dependant on the structural nature and the stability of the macro-molecular species that form in conjunction with the HS.

Due to its differentiated applicability and toxicity, mercury has been the focus of special attention on a global level. ${ }^{19}$ Elevated levels of mercury have been detected in aquatic Amazonian soils and systems in localities geographically distant from anthropic emissions sources. ${ }^{20-25}$ As a global pollutant derived from natural and anthropic processes, mercury has a permanence time in the atmosphere which is relatively long and is transported via dry and/or wet atmospheric depositing. Intensive intemperisms and lixiviation over the most part of the year have led to the diminishing of cations in the soil. Thus, cations, mercury ions for example, can be lixiviated from the soil to the Negro River. In this case, mercury OM interpretation studies are of fundamental importance in order to help elucidate the environmental dynamics of mercury.

In this work, the influence of the water regime on the structural characteristics and properties of AHS in the Amazonian environment are being investigated, mainly in relation to their interaction with $\mathrm{Hg}$ (II) and the results were interpreted using hierarchical cluster analysis (HCA) and principal component analysis (PCA).

\section{Experimental}

The HS were extracted from water samples collected monthly from the Negro River (State of Amazonas-AMBrazil) over a period of twelve months. The atomic ratio parameters of the $\mathrm{C} / \mathrm{H}, \mathrm{C} / \mathrm{N}$ and $\mathrm{C} / \mathrm{O}$, functional groups (obtained by ${ }^{13} \mathrm{C}$ nuclear magnetic resonance spectroscopy), concentration of semiquinone-type free radicals (determined by electronic paramagnetic resonance spectroscopy), $\mathrm{pH}$, pluviometric and fluviometric indices, concentrations of mercury were interpreted using HCA and PCA. 


\section{Reagents}

Reagents of analytical grade were used and the solutions were prepared using deionized water (Milli-Q, Millipore system).

\section{Water sample collection}

Monthly water-sample collections were done over the period of one year to verify the influence of seasonality on the structural characteristics and behavior of the AHS in the Amazonian environment. The water-sample collection points were situated on the left-hand bank of the Negro River-AM, between two tributaries, the Rio Tarumã Mirim and the Rio Tarumã Açu. This location was about $20 \mathrm{~km}$ west of the city of Manaus-AM (Figure 1).

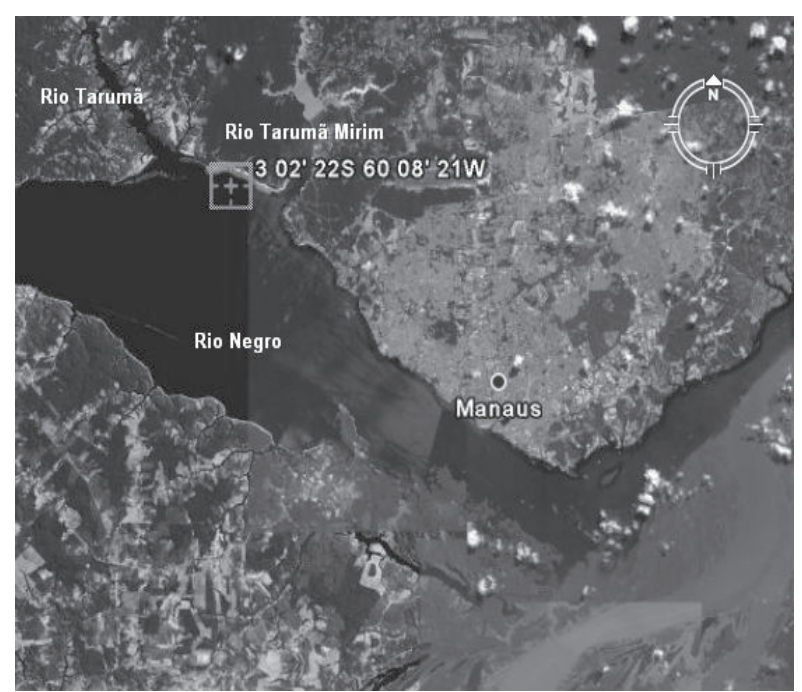

Figure 1. Map showing the sampling location site. The collection points are situated on the left-hand bank of the Negro River, between of the Tarumã River (T) and of the Tarumã Mirim River (TM).

\section{Extraction of the aquatic humic substances using XAD-8 resin}

The macro-porous resin, XAD-8, utilized to extract the AHS was previously purified by successive processing with hydrochloric acid $0.50 \mathrm{~mol} \mathrm{\textrm {L } ^ { - 1 }}$, sodium hydroxide $0.50 \mathrm{~mol} \mathrm{~L}^{-1}$ and methanol respectively ( $24 \mathrm{~h}$ for each process). To realize the extraction, the procedure recommended by the International Humic Substances Society (IHSS) was used. ${ }^{26}$ The samples were filtered using a filtration system under vacuum having Whatman 42 filter paper and then they were acidified with hydrochloric acid solutions of $6.0 \mathrm{~mol} \mathrm{~L}^{-1}$ until a $\mathrm{pH}$ of 3.0 was reached. Then the samples were percolated by gravity through glass columns ( $2 \mathrm{~cm}$ internal diameter and $25 \mathrm{~cm}$ tall) packed with XAD- 8 resin, having a flow rate of $4 \mathrm{~mL} \mathrm{~min}{ }^{-1}$. After saturation, verified by the darkening of the resin, $10 \mathrm{~mL}$ of $0.01 \mathrm{~mol} \mathrm{~L}^{-1}$ hydrochloric acid was used to remove impurities and then eluted in $0.10 \mathrm{~mol} \mathrm{~L}^{-1}$ sodium

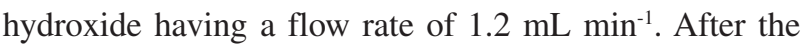
first elution, the resin was purified and the columns were once again put into operation. The $\mathrm{pH}$ of the final humic extract was adjusted to 5.0 (a $\mathrm{pH}$ similar to the Negro River water samples) using $0.10 \mathrm{~mol} \mathrm{~L}^{-1}$ hydrochloric acid.

\section{Purification of the humic extracts}

Dialysis membranes were prepared (Samless cell 16 $\mathrm{X} 100$ clear) according to the procedure described by Town and Powell ${ }^{27}$ After treating for $10 \mathrm{~min}$ in a $2 \%$ solution of sodium bicarbonate and a solution of disodium dihydrate EDTA at $0.01 \mathrm{~mol} \mathrm{~L}^{-1}$, the membranes were washed with deionized water at $65^{\circ} \mathrm{C}$ and put in a refrigerator at about $4{ }^{\circ} \mathrm{C}$. The humic extract was concentrated in a rotating evaporator and was purified using the dialysis membrane against deionized water until it gave a negative test for chlorides (a test using silver nitrate solution at $0.10 \mathrm{~mol}$ $\left.\mathrm{L}^{-1}\right)$. After removing the excess dissolved salts via dialysis, the humic extract was lyophilized according to the procedure described by Pitombo $^{28}$ and the material was then stored in petri dishes in a dessecator.

\section{Characterization of the aquatic humic substance samples}

\section{Elemental analysis}

Carbon, hydrogen, nitrogen, sulfur and oxygen were determined in triplicate in the Thermo Finigam Flash EA1112 equipment.

\section{Electronic Paramagnetic Resonance (EPR)}

The EPR spectra were acquired in a Bruker EMX spectrometer operating in the X-band $(\sim 9 \mathrm{GHz})$ at room temperature. For quantitative analysis, quartz tubes were filled with freeze-dried AHS samples, noting down their respective masses for later normalization of the data. To obtain the areas of the signals, the $I \times\left(\Delta H_{P P}\right)^{2}$ approximation was used, ${ }^{29}$ where $I$ is the derivative signal intensity and $\Delta H_{P P}$ is the peak-to-peak line width. To determine the relative concentration of semiquinone-type free radicals (OFR), also defined in the text as concentration of spins (in spins $\mathrm{g}^{-1}$ of $\mathrm{C}$ ); the signal area of the AHS samples was compared with a standard ("strong pitch") of known concentration of spins supplied by Bruker. It was used too a secondary standard in according to Singer's method ${ }^{18,30}$ to detect possible alterations in the Q-values of the EPR cavity. The experimental parameters were the following: $0.2 \mathrm{~mW}$ for the microwave power 
(determined by a power saturation experiment) ${ }^{31} 100 \mathrm{kHz}$ for the modulation frequency; $0.1 \mathrm{mT}$ for the modulation amplitude; $2.56 \mathrm{~ms}$ for the time constant and $10.24 \mathrm{~ms}$ for time conversion. The analyses were carried out in duplicate to obtain the medium deviation with at least sixteen sweeps per determination.

\section{Nuclear Magnetic Resonance $\left({ }^{13} \mathrm{C} N \mathrm{NM}\right)$}

The ${ }^{13} \mathrm{C}$ NMR experiments with cross polarization (CP), magic angle rotation (MAS) and variable amplitude (VA) were carried out in a Varian Spectrometer (model Unity Inova 400). The samples were conditioned in a cylindrical zirconium rotor, being $5 \mathrm{~mm}$ in diameter (Doty Supersonic), rotating at $6 \mathrm{KHz}$ in a Doty Supersonic probe for solid samples. The VACP/MAS ${ }^{13} \mathrm{C}$ NMR spectra were obtained under the following experimental conditions: a resonance frequency of $100 \mathrm{MHz}$ for ${ }^{13} \mathrm{C}$, a spectral band of $20 \mathrm{KHz}$, a proton preparation pulse of $3.8 \mu \mathrm{s}$, a contact time of $1 \mathrm{~ms}$, an acquisition time of $12.8 \mathrm{~ms}$ and a relax waiting time of $500 \mathrm{~ms}$. As a reference of the chemical shift in the spectra, hexamethilbenzene (HMB) was used.

\section{Digestion of the AHS samples and the determination of mercury}

To $0.20 \mathrm{~g}$ of AHS, $5.0 \mathrm{ml}$ of hydrogen peroxide solution (30\% solution) was added slowly and under agitation to solubilize the AHS. When the sample was totally dissolved, $15.0 \mathrm{~mL}$ of sulfonitric solution was added slowly to give a ratio of 1:1 (v/v) while keeping the sample solution in an ice bath. The solution was heated for one hour to a temperature of $70^{\circ} \mathrm{C}$ and then after cooling to room temperature, $10.0 \mathrm{~mL}$ of potassium permagamate $(7.5 \% \mathrm{~m} / \mathrm{v})$ was added. After $15 \mathrm{~min}, 5.0 \mathrm{~mL}$ of potassium persulphate $(8 \% \mathrm{~m} / \mathrm{v})$ was added. The solutions containing the AHS samples were heated for two hours to $70^{\circ} \mathrm{C}$ and then they were left to rest for twelve hours. Hidroxilamine chloride solution $(12 \% \mathrm{~m} / \mathrm{v})$ was added, sufficient to reduce the remaining potassium permagamate and then shortly afterwards mercury determinations were undertaken using atomic absorption spectrometry with cold vapor generation. ${ }^{32,33}$

\section{Results and Discussion}

In environmental studies where generally a great number of variables must be considered simultaneously, multivaried techniques have been shown to be efficient in evaluating correlations and interpreting the results obtained. In this case, Principal Component Analysis (PCA) and Hierarchical Cluster Analysis (HCA) have been the most utilized. ${ }^{34,35}$ The PCA reduces the dimension of the original data, facilitating the interpretation of the more important information in a lesser number of main factors or components. HCA has as objective, the observation of formation of natural groups in a hierarchical structure in which the samples are placed in a system of groups and subgroups depending on the degree of similarity between them.

According to fluviometric indices, the Amazonian region is influenced by high-water and low-water periods. The average levels between March/02 and February/03 showed that the lowest water levels occurred between October and November (between $18.67 \mathrm{~m}$ and $19.69 \mathrm{~m}$ ) and the highest between June and July (28.7 m) (Table 1). In the flooding (high-water) periods, the waters of the Negro River flood the forests, the marshes and streams. As of June, the low-water levels begin taking the waters out of the forests and in the dry season, between October and February, the streams remain in small channels. The low $\mathrm{pH}$ of the water in the tributaries of the Negro River is due to the great transport of various HS from extensive areas of hydromorphic podzols in the superior portion of the basin. The conductivity values $\left(\mathrm{mS} \mathrm{cm}^{-1}\right)$ of the socalled black waters indicated their low content of dissolved solids, corroborating with Fadini and Jardim, ${ }^{20}$ who

Table 1. Pluviometric and fluviometric indices and complementary information related to the water samples from Negro River-AM

\begin{tabular}{|c|c|c|c|c|c|c|}
\hline AHS & Months of sampling & $\begin{array}{l}\text { Pluviometric index/ } \\
\qquad(\mathrm{mm})\end{array}$ & $\begin{array}{l}\text { Fluviometric index/ } \\
\qquad(\mathrm{mm})\end{array}$ & $\mathrm{pH}$ & $\begin{array}{l}\text { Temperature/ } \\
\left({ }^{\circ} \mathrm{C}\right)\end{array}$ & $\begin{array}{l}\text { Conductivity/ } \\
\quad\left(\mu \mathrm{S} \mathrm{cm}^{-1}\right)\end{array}$ \\
\hline 1 & March/2002 & 310 & 24.4 & 4.5 & 29 & 13 \\
\hline 2 & April/2002 & 290 & 26.1 & 4.5 & 26 & 12 \\
\hline 3 & May/2002 & 260 & 27.6 & 4.5 & 25 & 13 \\
\hline 4 & June/2002 & 100 & 28.7 & 4.5 & 35 & 10 \\
\hline 5 & July/2002 & 90 & 28.7 & 4.5 & 32 & 9 \\
\hline 6 & August/2002 & 60 & 27.4 & 4.5 & 34 & 11 \\
\hline 7 & September/2002 & 80 & 24.8 & 5.0 & 32 & 10 \\
\hline 8 & October/2002 & 110 & 19.7 & 5.0 & 34 & 11 \\
\hline 9 & November/2002 & 180 & 18.7 & 4.5 & 33 & 11 \\
\hline 10 & December/2002 & 210 & 20.9 & 4.4 & 33 & 11 \\
\hline 11 & January/2003 & 260 & 22.12 & 4.7 & 31 & 13 \\
\hline 12 & February/2003 & 290 & 22.3 & 4.8 & 31 & 12 \\
\hline
\end{tabular}


determined the average conductivity to be about $15 \mu \mathrm{S}$ $\mathrm{cm}^{-1}$ in water samples taken from the Negro River.

The H/C, C/N, C/O atomic ratios obtained from element analysis (Table 2) have been utilized to aid the characterization of HS and the comparison of HS from different matrices can indicate the degree of similarity between them. Utilizing these ratios, Leenheer ${ }^{36}$ and Ertel et al. ${ }^{37}$ verified structural similarities of AHS in comparison with HS from soil samples from the central-Amazonian-basin region indicating that the AHS from black-water rivers are originally from podzol-type soils.

The $\mathrm{H} / \mathrm{C}$ and $\mathrm{C} / \mathrm{N}$ atomic ratios give an indication of the structure and molecular shape of the HS. ${ }^{38}$ The hydrogen content is related to the degree of saturation. Or in other words, an increase in the hydrogen content indicates a greater number of aliphatic carbons $\left(\mathrm{CH}_{2}\right)$ than aromatic carbons $(\mathrm{C}=\mathrm{C}) .{ }^{39}$ The values of the $\mathrm{H} / \mathrm{C}$ atomic ratios for samples of AHS vary between 1.17 and 1.33 (Table 2).

These values are close to the ones cited in literature for related researchers (Table 3). The samples indicate carbon atoms having more aliphatic characteristics when compared with the data of Leenheer ${ }^{36}$ and Ertel et al..$^{37}$ However, in relation to the data obtained by Sargentini et $a l,{ }^{40}$ the samples present more aromatic characteristics.

The $\mathrm{C} / \mathrm{N}$ atomic ratios varied between 17.1 and 27.4 indicating a seasonal influence in the degree of humification of the AHS. Comparing the $\mathrm{C} / \mathrm{N}$ atomic ratios with those found in literature (Table 3), there is an inference of a lesser degree of humification of the AHS samples utilized in this study, but also comparable to values obtained for OM extracted from samples taken from the Amazon River having particle sizes between 0.1 and $63 \mu \mathrm{m} .^{41}$

The $\mathrm{C} / \mathrm{O}$ atomic ratio is related to the carbohydrate content of the HS. Elevated values of this ratio indicate a greater degree of humification due to the diminishing of carbohydrate content. ${ }^{7}$ Values of $\mathrm{O} / \mathrm{C}$ can also represent a greater presence of $\mathrm{COOH}$ and $\mathrm{OH}$ groups (both aromatic and aliphatic). From the results obtained, it can be observed that the $\mathrm{C} / \mathrm{O}$ atomic ratios vary between 1.32 and 2.20, inferring differences in the degree of humification of the AHS.

The ${ }^{13} \mathrm{C}$ NMR results indicated significant differences in the content of functional groups present in the samples

Table 2. H/C, C/N and C/O atomic ratios, spin concentration (spins ( $\mathrm{g} \mathrm{C}^{-1}$ ) of aquatic humic substances extracted from Negro River-AM

\begin{tabular}{|c|c|c|c|c|}
\hline \multirow[t]{2}{*}{ Samples } & \multicolumn{3}{|c|}{ Atomic ratios } & \multirow[t]{2}{*}{ Spins $\left(\mathrm{g} \mathrm{C}^{-1} \times 10^{17}\right.$} \\
\hline & $\mathrm{H} / \mathrm{C}$ & $\mathrm{C} / \mathrm{N}$ & $\mathrm{C} / \mathrm{O}$ & \\
\hline 1 & $1.2 \pm 0.2$ & $26.5 \pm 1.8$ & $1.4 \pm 0.3$ & $1.61 \pm 0.03$ \\
\hline 2 & $1.2 \pm 0.1$ & $24.8 \pm 1.6$ & $1.6 \pm 0.5$ & $1.05 \pm 0.03$ \\
\hline 3 & $1.3 \pm 0.1$ & $27.4 \pm 2.2$ & $1.6 \pm 0.2$ & $1.54 \pm 0.05$ \\
\hline 4 & $1.2 \pm 0.2$ & $26.2 \pm 1.9$ & $1.6 \pm 0.2$ & $1.14 \pm 0.04$ \\
\hline 5 & $1.2 \pm 0.3$ & $23.6 \pm 1.3$ & $1.8 \pm 0.1$ & $0.78 \pm 0.02$ \\
\hline 6 & $1.3 \pm 0.2$ & $21.8 \pm 1.0$ & $1.8 \pm 0.3$ & $0.49 \pm 0.01$ \\
\hline 7 & $1.3 \pm 0.2$ & $21.0 \pm 0.9$ & $1.8 \pm 0.4$ & $0.84 \pm 0.02$ \\
\hline 8 & $1.3 \pm 0.1$ & $20.7 \pm 2.1$ & $1.7 \pm 0.5$ & $0.82 \pm 0.02$ \\
\hline 9 & $1.3 \pm 0.2$ & $24.4 \pm 1.8$ & $1.6 \pm 0.2$ & $1.89 \pm 0.03$ \\
\hline 10 & $1.3 \pm 0.1$ & $24.8 \pm 1.6$ & $1.6 \pm 0.3$ & $1.60 \pm 0.02$ \\
\hline 11 & $1.2 \pm 0.3$ & $17.1 \pm 0.5$ & $2.2 \pm 0.5$ & $2.81 \pm 0.04$ \\
\hline 12 & $1.3 \pm 0.1$ & $23.9 \pm 0.7$ & $2.0 \pm 0.1$ & $1.43 \pm 0.02$ \\
\hline
\end{tabular}

Table 3. Atomic ratios $(\mathrm{H} / \mathrm{C}, \mathrm{C} / \mathrm{N}$ e $\mathrm{C} / \mathrm{O})$ of different samples of humic substance according to the literature

\begin{tabular}{|c|c|c|c|c|}
\hline \multirow[t]{2}{*}{ Samples } & \multicolumn{3}{|c|}{ Atomic ratios } & \multirow[t]{2}{*}{ References } \\
\hline & $\mathrm{H} / \mathrm{C}$ & $\mathrm{C} / \mathrm{N}$ & $\mathrm{C} / \mathrm{O}$ & \\
\hline AHS (Negro River ) & 1.18 & 33.3 & 1.42 & Leenheer ${ }^{36}$ \\
\hline AHS (Negro River ) & 1.70 & 25.6 & 1.60 & Sargentini et al. ${ }^{40}$ \\
\hline HA (Negro River ) & 1.47 & 24.7 & 0.98 & Sargentini et al. ${ }^{40}$ \\
\hline FA (Negro River ) & 1.52 & 24.7 & 0.97 & Sargentini et al. ${ }^{40}$ \\
\hline HA (Negro River ) & 0.79 & 58.1 & nd & Ertel et $a .^{37}$ \\
\hline FA (Negro River) & 0.95 & 85.0 & nd & Ertel et al. ${ }^{37}$ \\
\hline DOM (Negro River) & nd & 25.0 & nd & McClain et al. ${ }^{1}$ \\
\hline OM particles $>63 \mathrm{~mm}$ (Amazon River) & nd & 24.0 & nd & Hedges et al..$^{41}$ \\
\hline OM particles (0.1-63 mm) (Amazon River) & nd & 15.0 & nd & Hedges et al. ${ }^{41}$ \\
\hline DOM (0.001-0.1 mm) (Amazon River) & nd & 34.0 & nd & Hedges et al..$^{41}$ \\
\hline
\end{tabular}

nd - not detected, AHS - aquatic humic substance, HA - humic acid, FA - fulvic acid, DOM - dissolved organic matter, OM - organic matter. 
of AHS (Table 4). The more aliphatic samples were extracted from water samples collected in the months of March/02; April/02 and May/02. And the more aromatic samples in the month of Oct/02, Nov/02; Dec/02; Jan/03 and $\mathrm{Feb} / 03$, thus giving inference to a greater degree of humification of these samples. Rocha et al. ${ }^{42}$ characterizing samples of AHS samples extracted from water collected in the Amazon region, observed a greater aromatic characteristic than for the samples studied in this work (Table 4).

The Organic Free Radicals (OFR) in HS, detectable using EPR, is attributed to semiquinone structures ${ }^{43}$ possibly conjugated to aromatic rings, being these groups formed in the OM from the oxidated dehydrogenation of phenolic compounds. ${ }^{7,44}$ According to Senesi, ${ }^{45}$ another possibility that cannot be excluded is the contribution from methoxybenzene and nitrogenassociated radicals. These are only hypotheses, since there is no consensus as yet as to the exact origin of the free radical signal in HS. ${ }^{45,46}$

It has been shown that the OFR concentration is proportional to the humification of the SOM. . $^{18,44,45,48,49}$ Normally, humification process is related to the content of aromatic compounds. ${ }^{50,51}$ Along with this, the determination of the OFR concentration gives an indirect estimation of the degree of aromaticity of the HS. ${ }^{43}$ Table 2 shows the values of the OFR concentration, where it can be seen that the values vary from $0.49 \times 10^{17}{\text { spins } \mathrm{g}^{-1}}^{-1}$ of $\mathrm{C}$ to $2.81 \times 10^{17}$ spins $\mathrm{g}^{-1}$ of $\mathrm{C}$ for samples 6 (Aug/02) and $11(\mathrm{Jan} / 03)$, respectively. These maximum and minimum values indicate a substantial variation in the OFR concentration of the AHS analyzed. However, these values are below the values normally encountered for humic acids from soil. ${ }^{18,52}$
The statistical methods of extrapolational analysis, hierarchical cluster analysis (HCA) and principal component analysis (PCA) were used to interpret the experimental data generated from the different determinations using STATISTICA 6.0 software. Hierarchical cluster analysis (Figure 2) showed the formation of three main groups: (A) $\mathrm{H} / \mathrm{C}$ atomic ratios, aliphatic carbon, carbonyl carbon and fluviometric index; (B) $\mathrm{C} / \mathrm{N}$, carboxyl carbon, OFR, and pluviometric index; (C) C/ $\mathrm{O}, \mathrm{pH}$, ether, aromatics, phenolics and the concentration of mercury.

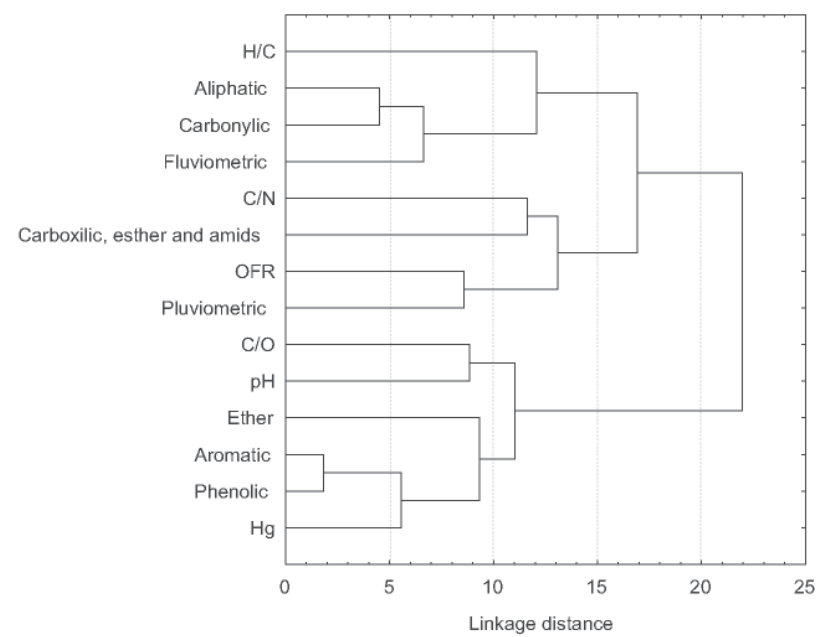

Figure 2. Dendogram of the parameters $(\mathrm{pH}$, atomic ratios, concentration of $\mathrm{Hg}$, OFR, functional groups, pluviometric and fluviometric indices) obtained by HCA.

Group "A" indicates correlation between the level of the river, AHS aliphaticity and therefore, $\mathrm{H} / \mathrm{C}$ ratio. In this way, the AHS extracted in the period where the fluviometric index is greater, the degree of humification of these AHS is smaller. Group "B" shows the direct

Table 4. Peak assignments for the ${ }^{13} \mathrm{C}$ NMR spectra of the aquatic humic substances extracted from Negro River and their integrated areas (\%)

\begin{tabular}{|c|c|c|c|c|c|}
\hline \multirow[t]{2}{*}{ Samples } & \multicolumn{5}{|c|}{ Assignments / Integration \% } \\
\hline & $\begin{array}{c}\text { Alkyl-C } \\
\text { Metoxyl and } \\
\text { Alkyl-N }(0-65 \text { ppm })\end{array}$ & $\begin{array}{c}\text { O-alkyl-C } \\
\text { (65-110 ppm) }\end{array}$ & $\begin{array}{l}\text { Aromatic and } \\
\text { Phenolic } \\
\text { (110-165 ppm) }\end{array}$ & $\begin{array}{c}\text { Carboxylic } \\
\text { Carbon } \\
(165-185 \mathrm{ppm})\end{array}$ & $\begin{array}{c}\text { Carbonylic } \\
\text { Carbon } \\
\text { (185-230 ppm) }\end{array}$ \\
\hline 1 & 53.1 & 17.1 & 9.3 & 9.6 & 10.9 \\
\hline 2 & 56.8 & 16.1 & 7.5 & 10.6 & 8.9 \\
\hline 3 & 65.1 & 5.6 & 9.1 & 10.3 & 9.9 \\
\hline 4 & 50.5 & 21.8 & 8.5 & 10.1 & 9.1 \\
\hline 5 & 47.9 & 24.3 & 9.2 & 9.3 & 9.3 \\
\hline 6 & 47.5 & 23.9 & 8.8 & 10.4 & 9.5 \\
\hline 7 & 47.5 & 23.3 & 11.2 & 10.0 & 8.1 \\
\hline 8 & 36.8 & 29.2 & 18.9 & 9.7 & 5.3 \\
\hline 9 & 36.6 & 29.4 & 18.5 & 10.2 & 5.3 \\
\hline 10 & 36.9 & 28.7 & 19.8 & 10.1 & 4.5 \\
\hline 11 & 37.1 & 28.9 & 19.8 & 9.6 & 4.6 \\
\hline 12 & 36.9 & 29.7 & 18.2 & 10.3 & 4.9 \\
\hline (Rocha et $a l . .^{42}$ ) & 33.0 & 17.0 & 35.0 & 12.0 & 3.0 \\
\hline
\end{tabular}


relationship between the $\mathrm{C} / \mathrm{N}$ atomic ratio, the $\mathrm{OFR}$, the pluviometric index and the carboxylic groups. These parameters are inter-linked by the degree of humification. Martin-Neto et al. ${ }^{18}$ encountered significant positive linear correlation between the OFR concentration and the pluviometric index. According to Stevenson, ${ }^{7}$ the $\mathrm{C} / \mathrm{N}$ atomic ratios is proportional to the HS humification degree. The presence of carboxylic groups in this cluster is probably due to the fact that these groups are the most oxidated and therefore related to the most refractory OM. Group "C" indicates that the greater the $\mathrm{C} / \mathrm{O}$ atomic ratio, the greater the aromaticity of these HS. Stevenson ${ }^{7}$ described the relationship between the $\mathrm{C} / \mathrm{H}, \mathrm{C} / \mathrm{N}$ and $\mathrm{C} / \mathrm{O}$ atomic ratios and the degree of humification of the $\mathrm{HS}$. According to the statistical analysis of Group " $C$ ", the mercury concentrations are also related to the $\mathrm{C} / \mathrm{O}$ atomic ratios, aromatic groups or, in other words, parameters that suggest a greater degree of humification of the HS. In this way, the greatest concentrations of mercury are present in the more humified AHS samples. Due to the buffering effect of the HS, the water $\mathrm{pH}$ does not vary significantly as observed in Table 1 , and so it is neither related to the fluviometric (Group "A") nor the pluviometric parameters (Group "B").

In Figure 3, the positive weights of fluviometric, carbonylic, aliphatic, $\mathrm{C} / \mathrm{N}$ and carboxylic variables and the negative weights of phenolic, aromatic, mercury concentration, $\mathrm{C} / \mathrm{O}$ and ester variables can be observed

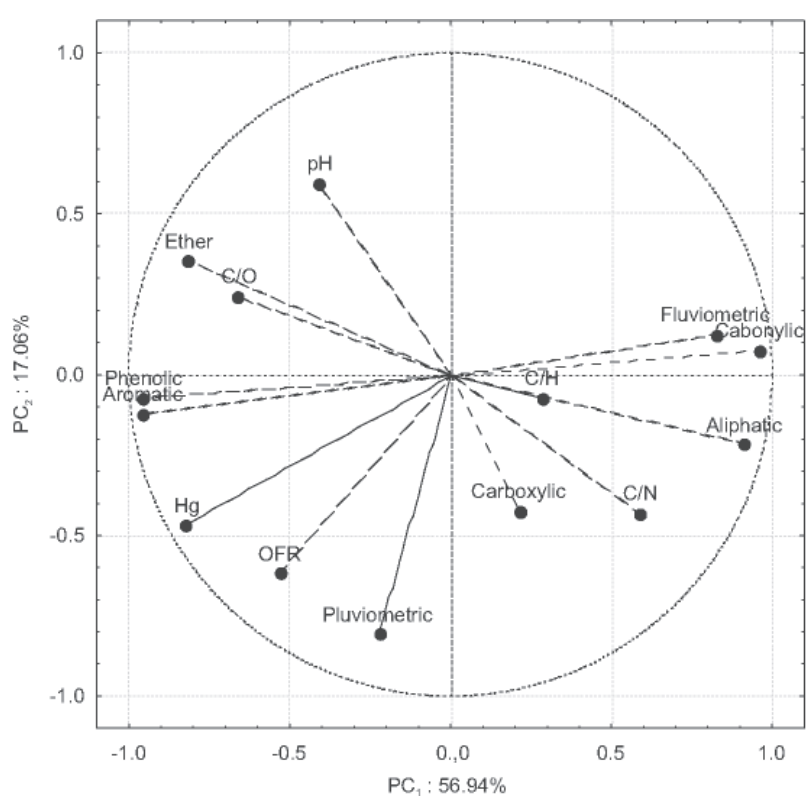

Figure 3. Principal component analysis of the whole data set. Correlations between the parameters $(\mathrm{pH}$, atomic ratios, concentration of $\mathrm{Hg}$, OFR, functional groups, pluviometric and fluviometric indices) and principal components in the projection of components 1 and 2. in the $\mathrm{PC}_{1}$, which explains $56.94 \%$ of the total variance of the data.

The positive-weight variables in the $\mathrm{PC}_{1}$ are related to the AHS containing a greater content of fulvic acids. This is observed due to the fluviometric index parameters along with the aliphatic, carbonylic and carboxylic groups having elevated positive values in this $\mathrm{CP}$. The negativeweight variables in the $\mathrm{PC}_{1}$ are related to the samples containing a greater humic acid content (the presence of phenolic and aromatic groups). When the fluviometric index is high (high-water periods), mainly the transport of more recently-formed OM occurs and so, the samples having positive values for this $\mathrm{PC}$ have a lesser degree of humification.

Due to the OFR concentration parameters, the concentration of mercury and the pluviometric index being negative-weight variables and having a strong influence over the $\mathrm{PC}_{2}$, this $\mathrm{PC}$ is related to the degree of humification of the HS. The OM lixiviation process for the aquatic system caused by the rains is evidenced in this CP. In this case, it refers to a slower drainage causing a dragging of $\mathrm{HS}$ in a more advanced state of decomposition. The samples with negative values for $\mathrm{PC}_{2}$ have a greater degree of humification and, as described in the previous paragraph, the samples with negative values for $\mathrm{PC}_{1}$ also have a greater degree of humification. And so it can be seen that samples with negative values for the two PCs have a greater degree of humification. In summary, analyzing the graphs of Figures 3 and 4

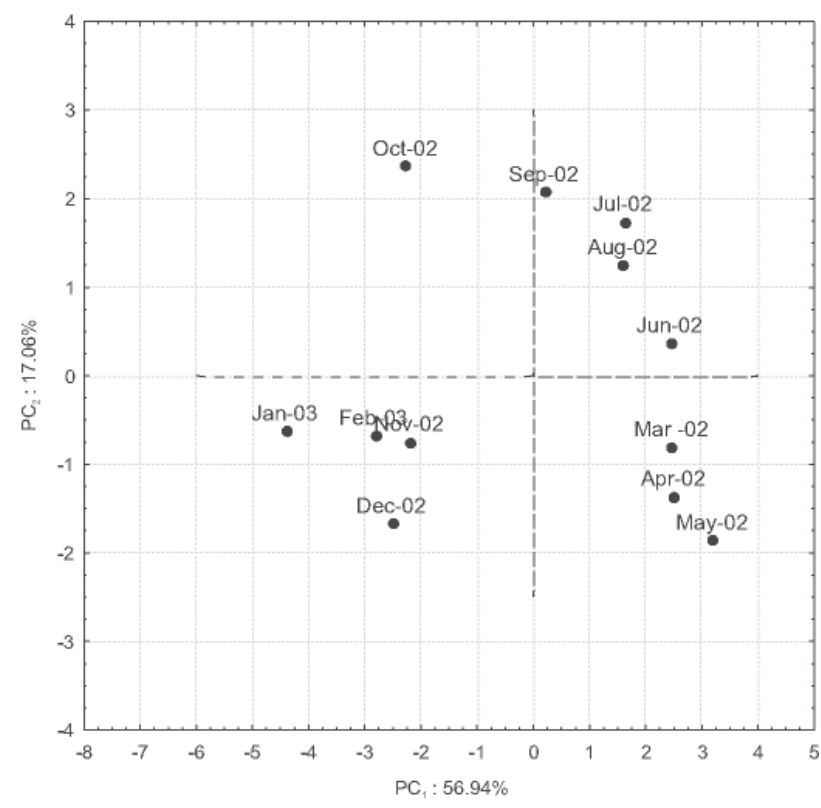

Figure 4. Principal component analysis of all samples studied. Correlations between the sample collected in different months and principal components in the projection of components 1 and 2 ( $\mathrm{PC}_{1}$ vs. $\mathrm{PC}_{2}$ loading biplot). 
together, the following decreasing order of AHS humification can be established as a function of seasonality: Nov/2002 to Feb/2003 > Mar/2002 to May/ $2002>$ Jun/02 to Oct/02.

The statistical analyses showed that the more humified samples have the greatest mercury content and the phenolic, aromatic and ester groups were predominant in their interaction with mercury. According to Sargentini et al., ${ }^{40}$ the metal-OM complex tends to stabilize itself as a function of time where inter and/or intra-molecular rearrangements occur with the transfer of the metal itself to the more internal complexation sites of humic structures. In this way, the results obtained show that the more humified samples having a greater content of the phenolic/aromatic/ester groups have a greater concentration of mercury possibly related to the lixiviation of more humified $\mathrm{OM}$ in the soil for the aquatic system.

\section{Conclusions}

The Amazon region is characterized by its great variety of soils with floodable and non-floodable areas having particular characteristics of biodiversity, temperature and humidity. The region's high-water and low-water regimes have a strong influence over the formation, properties and the characteristics of the humic material present in the rivers of the region, which was evidenced by the multivaried analyses undertaken. According to statistical analysis, the following decreasing order of the humification degree can be established: Nov/02 to Feb/03 > Mar/02 to May/02 > Jun/02 to Oct/02. These results show that the greater the level of the river, the lower the degree of humification of the AHS. The relationships obtained from the HCA showed strong correlation between pluviometric index, concentration of semiquinone-type free radicals and the $\mathrm{C} / \mathrm{N}$ atomic ratio, parameters which are related to a greater degree of humification. This shows that the pluviometric index is directly related to more humified OM.

Thus, the greater pluviometric index and the smaller fluviometric index, the greater the humification degree of the AHS. Along with this, the statistical analyses showed that the mercury concentrations are related to the more humified AHS samples and have greater interaction with samples having greater aromatic/ phenolic/ester group content. In other words, the humification degree is proportional to the stability of the metal-OM complex due to inter and/or intramolecular rearrangements bringing about transfers between the metal itself to the more internal complexation sites of the humic structures.

\section{Acknowledgments}

Thanks to FAPESP, CNPq, CAPES and FUNDUNESP for their financial support and study fellowships.

\section{References}

1. McClain, M.E.; Richey, J.E.; Brandes, J.A.; Global Biogeochem. Cycles 1997, 11, 295.

2. Bluntschli, H. A.; Cadernos da Amazônia 1921, 1, 1.

3. Sioli, H.; Amazônia: Fundamentos da Ecologia da Maior Região de Florestas Tropicais, Vozes: Petrópolis, 1985.

4. Spitzy, A.; Ittekkot, V.; In Ocean Margin Processes in Global Change; Mantoura, R.F.C.; Martin, J.M.; Wollast, R., eds., John Wiley: Chichester, 1991, pp. 5-17.

5. Ivanissevich, A.; Ciência Hoje 1990, 11, 47.

6. Ravichandran, M.; Chemosphere 2004, 55, 319.

7. Stevenson, F. J.; Humus Chemistry, $2^{\text {nd }}$ ed., Wiley: New York, 1994.

8. Schulten, H.R.; Schnitzer, M.; Naturwissenschaften 1995, 82, 487.

9. Clapp, C. E.; Hayes, M.H.B.; Soil Sci. 1999, 164, 777.

10. Burdon, J.; Soil Sci. 2001, 66, 752.

11. Hayes, M. H. B.; Clapp, C.E.; Soil Sci. 2001, 166, 723.

12. Piccolo, A.; Soil Sci. 2001, 166, 810.

13. Thurman, E. M. ; Malcolm, R. L.; Environ. Sci. Technol. 1981, $15,463$.

14. Piccolo, A.; In Humic Substances Versatile Components of Plants, Soil And Water; Davies, G.; Ghabbour, E.A., eds., Royal Society of Chemistry: Cornwall, 2000, pp. 111-124.

15. Rosa, A. H.; Simões, M. L.; Oliveira, L. C.; Rocha, J. C.; MartinNeto, L.; Milori, D. P. M. B.; Geoderma 2005, 127, 1.

16. Baldock, J. A.; Oades, J. M.; Waters, A. G.; Peng, X.; Vassalo, A. M.; Wilson, M. A.; Biogeochemistry 1992, 16, 1.

17. Quideau, S.A.; Chadwick, O.A.; Benesi, A.; Graham, R.C.; Anderson, M. A.; Geoderma 2001, 104, 41.

18. Martin-Neto, L.; Rosell, R.; Sposito, G.; Geoderma 1998, 81, 305.

19. Bringmarck, L.; In Mercury And its Effects on Environment and Biology. Sigel, A.; Sigel, H. eds, Marcel Dekker: New York, 1997.

20. Fadini, P. S.; Jardim, W. F.; Sci. Total Environ. 2001, 275, 71.

21. Oliveira, S. B.; Melfi, A. J.; Fostier, A. H.; Forti, M. C.; Favaro, D. I. T.; Boulet, R. ; Water, Air, Soil Pollut. 2001, 26, 321.

22. Valle, C. M.; Santana, G. P.; Augusti, R.; Egreja Filho, F. B.; Windmoller, C. C. ; Chemosphere 2005, 58, 779.

23. Barbosa, A. C.; Souza, J.; Dórea, J. G.; Jardim, W. F.; Fadini, P. S. ; Arch. Environ. Contam. Toxicol. 2003, 45, 235.

24. Forsberg, M.C.S.; Forsberg, B.R.; Zeidemann, V.K.; Ambio 1999, 285,19.

25. Malm, O.; Pfeiffer, W. C.; Souza, C. M. M.; Reuther,; R. Ambio 1990, 19, 11 
26. Malcolm, R.; Thurman, E. M. In Aquatic and Terrestrial Humic Materials; Christman, R. F.; Gjessing, E. T.; eds., Ann Habor Science: Ann Arbor, 1985.

27. Town, R. M.; Powell, H. K. J.; Anal. Chim. Acta 1992, 256, 81.

28. Pitombo, R.N.M.; Ciência e Cultura (SBPC) 1989, 41, 427.

29. Poole Jr., C.P.; Electron Spin Resonance: A Comprehensive Treatise on Experimental Techniques, Wiley: New York, 1967.

30. Singer, L.S.; J. Appl. Phys. 1959, 30, 1463.

31. Weil, J. A.; Bolton, J. R.; Wertz, J. E.; Electron Paramagnetic Resonance: Elementary Theory and Practical Applications, Willey: New York, 1994.

32. Rocha, J.C.; Santos, A.; Sene, J.J.; Eclética Química 1994, 19, 119.

33. Jackwerth, E.; Wilmer, P. G.; Hohn, R.; Berndt, H.; At. Absorpt. Newsl. 1979, 18, 66.

34. Burns, W. A.; Mankiewicz, P. J.; Bence, A. E.; Page, D. S.; Parkers, K. R. A.; Environ. Toxicol. Chem. 1997, 16, 1119.

35. Salau, J. S. I.; Tauler, R.; Bayona, J. M.; Tolosa I.; Environ. Sci. Technol. 1997, 31, 3482.

36. Leenheer, J. A.; Acta Amazonica 1980, 10, 513.

37. Ertel, J.; Hedges, J. I.; Richey, J. E.; Devol, A. H.; Richey, J. E.; Ribeiro, M. N. G.; Limnol. Oceanogr. 1986, 31, 739.

38. Steelink, C. In Implications of Elemental Characteristics of Humic Substances. Aiken, G. R.; Mcknight, M. D.; Wershaw, R. L.; Maccarthy, P.; eds., John Wiley \& Sons: New York, 1985.

39. Traina, S. J. ; Novak, J.; Smeck, N. E.; J. Environ. Qual. 1990, 19, 151.

40. Sargentini Jr. E., Rocha, J. C.; Rosa, A. H.; Zara, L. F.; Santos, A.; Quim. Nova 2001, 24, 339.
41. Hedges, J. I.; Mayorga, E.; Tsamakis, E.; McClain, M. E.; Aufdenkampe, A.; Quay, P.; Richey, J. E. Limnol. Oceanogr. 2000, 45, 1449.

42. Rocha, J. C.; Sargentini Jr., E.; Toscano, I. A. S.; Rosa, A. H.; Burba, P.; J. Braz. Chem. Soc. 1999, 10, 169.

43. Budziak, C.R.; Maia, C.M.B.F.; Mangrich, A.S.; Quim. Nova 2004, 27, 399.

44. Riffaldi, R.; Schnitzer, M.; Soil Sci. Soc. Am. Proc. 1972, 36, 301.

45. Senesi, N.; Adv. Soil. Sci. 1990, 14, 77.

46. Cheshire, M.V.; Mcpahil, D.B.; European. J. Soil Sci. 1996, 47, 205.

47. Olk, D.C.; Brunetti, G., Senesi, N.; Soil Sci. Soc. Am. J. 2000, 64, 1337.

48. Novotny, E. H.; Martin-Neto, L.; Geoderma 2002, 106, 305.

49. Pajaczkowska, J.; Sulkowska, A.; Sulkowski, W.W.; Jedrzejczyk, M.; J. Mol. Struct., 2003, 651, 141.

50. Kögel-Knabner, I.; Zech, W.; Hatcher, P.G.; Soil Sci. Soc. Am. J. 1991, 55, 241.

51. Leinweber, P.; Fründ, R.; Reuter, G. Z.; Pflanzernernähr. Bodenk. 1993, 156, 415.

52. Martin-Neto, L.; Andriullo, A. E.; Traghetta, D.G.; Soil Sci. 1994, 157, 365 .

Received: October 16, 2006

Web Release Date: July 19, 2007

FAPESP helped in meeting the publication costs of this article. 